\title{
Water quality assessment of Gautami-Godavari mangrove estuarine ecosystem of Andhra Pradesh, India during September 2001
}

\author{
S C Tripathy*, A K Ray, S Patra and V V Sarma \\ National Institute of Oceanography, Regional Centre, 176, Lawson's Bay Colony, Visakhapatnam 530 017, India. \\ *e-mail: sctripathy@rediffmail.com
}

Some chemical and biological parameters were analysed at sixteen stations in the mangrove ecosystem, of the neighbouring Gautami-Godavari (GG) river estuary and Kakinada (KKD) bay to understand the present status of water quality and the impact of external terrigenous inputs during southwest (SW) monsoon in the study areas. High concentrations of nutrients in the mangrove ecosystem compared to the bay and estuarine ecosystems reveal the importance of this zone as a source of nutrients to the adjacent coastal ecosystems. Low Si:N:P (29:4:1) ratios in these ecosystems are due to the enrichment of these nutrients through external anthropogenic inputs even after the utilization by phytoplankton in the biological cycle. The mean $\mathrm{Chl} b / \mathrm{Chl} a$ and $\mathrm{Chl} c / \mathrm{Chl} a$ ratios and high phaeopigments $(\mathrm{Pp})$ concentrations compared to $\mathrm{Chl} b$ and high ratios of Chl $a / \mathrm{Pp}$ suggests the possibility of the potential growth of phytoplankton populations in lower light intensity and low turbulent areas of these mangrove ecosystems.

\section{Introduction}

Mangrove forests are considered to be highly productive tropical ecosystems (Clough 1992). Mangrove areas are ecologically sensitive and provide physical protection for the communities, more importantly they are believed to play a major role in supporting tropical estuarine and coastal food webs (Alongi and Christoffersen 1992). It is a fact that the mangrove forests represent an important carbon and nutrient source to the adjacent lagoonal and coastal systems (Odum and Heald 1972, 1975; Twilley 1988; Wattayakorn et al 1990; Robertson et al 1992). The Coringa river mangrove ecosystem is the second largest coastal ecosystem in the east coast of India, connected to Kakinada bay on its north and to the Gautami-Godavari on its south. The presence of numerous canals, river tributaries along with dense mangrove vegetation makes it a unique habitat. However, it is noticed that the increasing pressure on mangrove forests due to urbanization, industrialization and intensive aquaculture poses a menace to this ecosystem.

Even though some biological and oceanographic studies in Godavari estuarine mangrove ecosystems were carried out earlier (Bouillon et al 2000; Dehairs et al 2000; Ranga Rao et al 2003; Bouillon et al 2003), detailed assessments of chemical characteristics were not reported till date. The present study was undertaken to understand the prevailing situation of the water quality and the impact of the anthropogenic input on this mangrove estuarine ecosystem during southwest monsoon.

\section{Materials and methods}

The study area (figure 1) comprises of sixteen stations covering the KKD bay (station $\mathrm{K}_{1}-\mathrm{K}_{5}$ ), GG estuarine region (station $\mathrm{G}_{1}-\mathrm{G}_{4}$ ) and the Gaderu river (station $\mathrm{M}_{1}-\mathrm{M}_{7}$ ) and Coringa river mangrove environment (station $\mathrm{M}_{3}-\mathrm{M}_{7}$ ). The Gaderu and Coringa are the branches of river Godavari, the

Keywords. Mangrove; estuary; water quality; nutrient; chlorophyll; phytoplankton. 


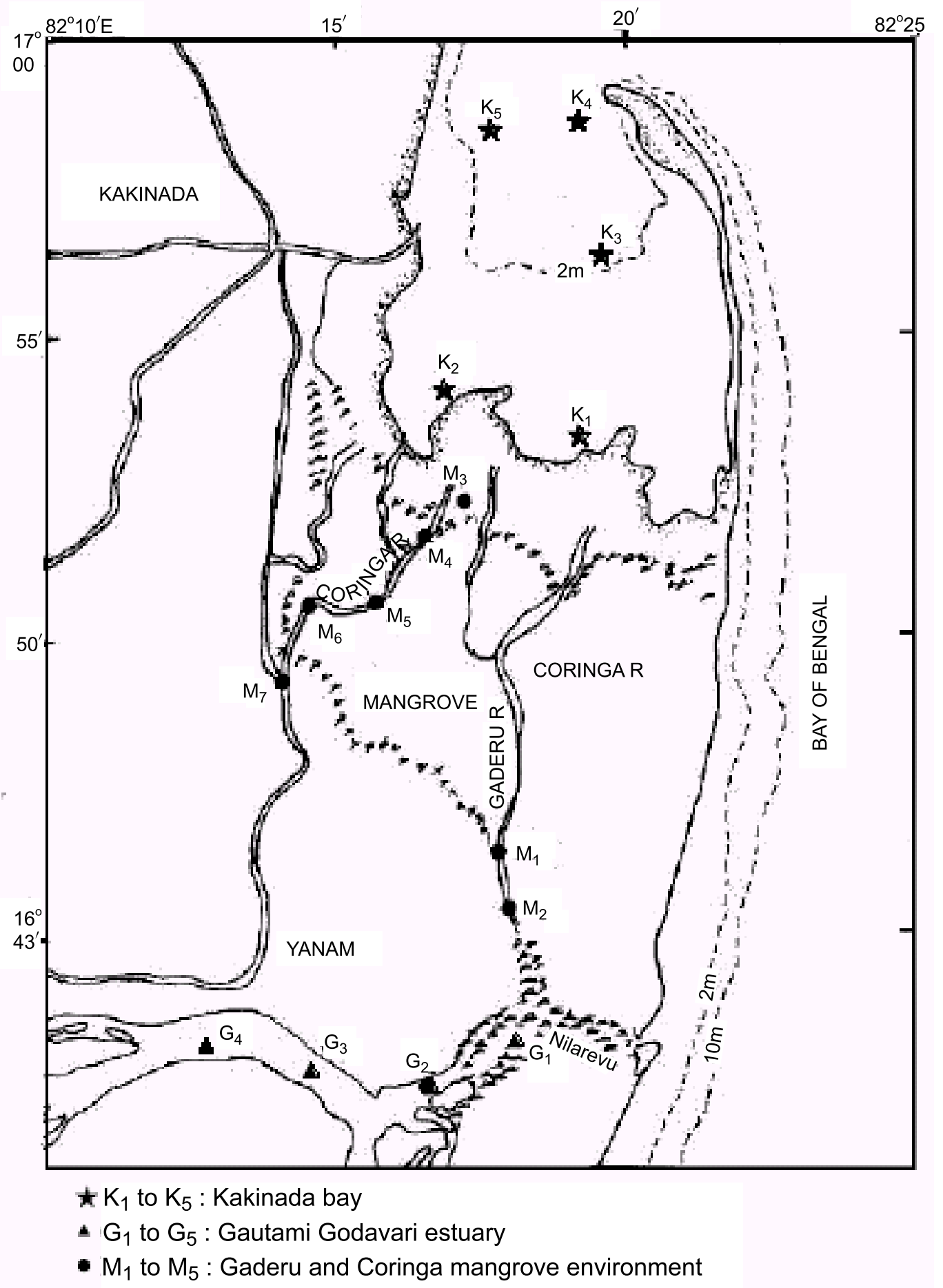

Figure 1. Station location map of the study area along Bay of Bengal.

second largest river in India with a mean annual discharge of $1.1 \times 10^{11} \mathrm{~m}^{3}$, of which $93-96 \%$ occurs during summer monsoon season. The extensive estuarine areas to the north of Gautami-Godavari $\left(82^{\circ} 15^{\prime}\right.$ and $82^{\circ} 22^{\prime} \mathrm{E} ; 16^{\circ} 43^{\prime}$ and $17^{\circ} 00^{\prime} \mathrm{N}$; area $=$ $132 \mathrm{~km}^{2}$ ) open into Kakinada bay via the main branches Gaderu (length $=11 \mathrm{~km}$ ) and Coringa (length $=26 \mathrm{~km}$ ). The area between GautamiGodavari and Kakinada bay has dense vegetation of mangrove forests and mudflats, which are an extension of Coringa Wildlife Sanctuary. The shallow Kakinada bay $\left(\right.$ area $=150 \mathrm{~km}^{2}$ ) opens into the sea on its northern side and is bordered along most of its eastern stretch by a narrow sand bar. Tides are semidiurnal and tidal amplitude in the bay varies between 2.3 and $4.5 \mathrm{~m}$, but in the mangrove covered area the tidal amplitude is comparatively low (Sreenivas 1998). 
Table 1. Range (in parenthesis) and mean values $( \pm S D)$ of water parameters in the three regions.

\begin{tabular}{|c|c|c|c|}
\hline Parameters & KKD bay region & GG estuary region & Mangrove region \\
\hline $\mathrm{NO}_{2}-\mathrm{N}(\mu \mathrm{M})$ & $\begin{array}{c}(0.50-2.24) \\
1.33 \pm 056\end{array}$ & $\begin{array}{c}(0.68-1.72) \\
1.23 \pm 0.39\end{array}$ & $\begin{array}{c}(1.21-6.49) \\
3.41 \pm 1.6\end{array}$ \\
\hline $\mathrm{NO}_{3}-\mathrm{N}(\mu \mathrm{M})$ & $\begin{array}{c}(0.86-12.5) \\
6.03 \pm 3.55\end{array}$ & $\begin{array}{l}(13.9-21.4) \\
17.18 \pm 2.64\end{array}$ & $\begin{array}{l}(7.47-16.2) \\
11.15 \pm 2.42\end{array}$ \\
\hline $\mathrm{NH}_{4}-\mathrm{N}(\mu \mathrm{M})$ & $\begin{array}{c}(0.82-2.49) \\
1.51 \pm 0.60\end{array}$ & $\begin{array}{c}(0.33-2.25) \\
1.13 \pm 0.54\end{array}$ & $\begin{array}{c}(0.79-14.2) \\
4.83 \pm 3.4\end{array}$ \\
\hline $\mathrm{PO}_{4}-\mathrm{P}(\mu \mathrm{M})$ & $\begin{array}{c}(0.92-6.9) \\
2.54 \pm 1.68\end{array}$ & $\begin{array}{c}(1.76-4.53) \\
3.05 \pm 1.09\end{array}$ & $\begin{array}{c}(1.89-5.85) \\
3.17 \pm 0.99\end{array}$ \\
\hline $\mathrm{SiO}_{4}-\mathrm{Si}(\mu \mathrm{M})$ & $\begin{array}{c}(9.26-57.7) \\
33.93 \pm 17.37\end{array}$ & $\begin{array}{l}(42.5-142.0) \\
90.38 \pm 35.39\end{array}$ & $\begin{aligned}(68.6 & -139.0) \\
102.35 & \pm 25.73\end{aligned}$ \\
\hline $\mathrm{TN}(\mu \mathrm{M})$ & $\begin{array}{l}(13.7-120.0) \\
59.95 \pm 40.79\end{array}$ & $\begin{array}{l}(15.8-42.6) \\
26.44 \pm 8.65\end{array}$ & $\begin{array}{l}(21.3-196.0) \\
43.02 \pm 45.94\end{array}$ \\
\hline $\mathrm{TP}(\mu \mathrm{M})$ & $\begin{array}{c}(2.01-15.5) \\
7.46 \pm 3.85\end{array}$ & $\begin{array}{c}(3.69-16.2) \\
8.4 \pm 3.99\end{array}$ & $\begin{array}{l}(2.46-21.7) \\
10.52 \pm 5.01\end{array}$ \\
\hline$p \mathrm{H}$ & $\begin{array}{c}(7.10-7.93) \\
7.55 \pm 0.28\end{array}$ & $\begin{array}{l}(7.2-7.8) \\
7.52 \pm 0.22\end{array}$ & $\begin{array}{c}(7.19-7.58) \\
7.42 \pm 0.13\end{array}$ \\
\hline Salinity (PSU) & $\begin{array}{l}(11.9-31.4) \\
21.06 \pm 6.76\end{array}$ & $\begin{array}{c}(0.27-9.65) \\
3.87 \pm 3.9\end{array}$ & $\begin{array}{c}(0.27-9.48) \\
3.29 \pm 3.88\end{array}$ \\
\hline $\mathrm{DO}\left(\mathrm{mg} \mathrm{l}^{-1}\right)$ & $\begin{array}{c}(5.85-8.65) \\
7.03 \pm 0.93\end{array}$ & $\begin{array}{c}(5.49-6.38) \\
5.87 \pm 0.33\end{array}$ & $\begin{array}{c}(1.39-5.45) \\
2.88 \pm 1.55\end{array}$ \\
\hline $\mathrm{BOD}\left(\mathrm{mg} \mathrm{l}^{-1}\right)$ & $\begin{array}{c}(2.88-5.85) \\
4.88 \pm 1.13\end{array}$ & $\begin{array}{c}(1.52-2.8) \\
2.32 \pm 0.5\end{array}$ & $\begin{array}{c}(3.68-6.12) \\
4.79 \pm 0.74\end{array}$ \\
\hline Chl $a\left(\mu \mathrm{g} \mathrm{l}^{-1}\right)$ & $\begin{array}{l}(0.68-25.9) \\
12.49 \pm 9.55\end{array}$ & $\begin{array}{c}(0.86-15.9) \\
5.23 \pm 4.84\end{array}$ & $\begin{array}{c}(2.36-16.2) \\
5.42 \pm 4.74\end{array}$ \\
\hline $\operatorname{Chl} b\left(\mu \mathrm{g} \mathrm{l}^{-1}\right)$ & $\begin{array}{c}(0.04-4.08) \\
1.1 \pm 1.21\end{array}$ & $\begin{array}{l}(\mathrm{ND}-2.41) \\
0.61 \pm 0.85\end{array}$ & $\begin{array}{l}(\mathrm{ND}-4.53) \\
1.48 \pm 1.44\end{array}$ \\
\hline $\operatorname{Chl} c\left(\mu \mathrm{g} \mathrm{l}^{-1}\right)$ & $\begin{array}{c}(0.15-7.17) \\
1.83 \pm 2.03\end{array}$ & $\begin{array}{l}(\mathrm{ND}-2.6) \\
0.87 \pm 0.94\end{array}$ & $\begin{array}{c}(0.05-12.9) \\
2.88 \pm 3.14\end{array}$ \\
\hline $\operatorname{Pp}\left(\mu \mathrm{g} \mathrm{l^{-1 }}\right)$ & $\begin{array}{c}(0.44-21.1) \\
7.92 \pm 7.22\end{array}$ & $\begin{array}{c}(\mathrm{ND}-7.05) \\
2.2 \pm 2.28\end{array}$ & $\begin{array}{c}(0.88-6.25) \\
3.16 \pm 1.72\end{array}$ \\
\hline
\end{tabular}

Seawater samples were collected (once) over a period of three successive days at all the 16 stations in the mangrove environment (figure 1) during September 2001. The samples were collected from surface and near bottom with the help of Niskin water samplers. The depth of the water column in the study area varied from $2-3 \mathrm{~m}$. Salinity, dissolved oxygen (DO), biochemical oxygen demand (BOD), $p \mathrm{H}$, nitrate-nitrogen $\left(\mathrm{NO}_{3}-\mathrm{N}\right)$, nitritenitrogen $\left(\mathrm{NO}_{2}-\mathrm{N}\right)$, ammonia-nitrogen $\left(\mathrm{NH}_{4}-\mathrm{N}\right)$, silicate-silicon $\left(\mathrm{SiO}_{4}-\mathrm{Si}\right)$, phosphate-phosphorous $\left(\mathrm{PO}_{4}-\mathrm{P}\right)$, total nitrogen $(\mathrm{TN})$ and total phosphorus (TP) were determined following standard methods (Grasshoff 1976). Chlorophyll a ( Chl a), $\mathrm{Chl} b$, Chl $c$ and $\mathrm{Pp}$ were extracted in $90 \%$ acetone and measured spectrophotometrically (Parsons et al 1984).

\section{Results and discussion}

The environmental parameters showed wide variations at different stations in the study region depending on the topography. Salinity showed highest values (31.4 psu) at $\mathrm{K}_{5}$ nearer to the coastal environment associated with low $\mathrm{SiO}_{4}(9.26 \mu \mathrm{M})$ and $\mathrm{PO}_{4}(0.92 \mu \mathrm{M})$ concentrations. Lowest value of salinity $(0.27 \mathrm{psu})$ was noticed in Coringa mangrove environment $\left(\mathrm{M}_{5}-\mathrm{M}_{7}\right)$, accompanying high $\mathrm{SiO}_{4}(139.0 \mu \mathrm{M})$ concentration due to the freshwater zone of this aquatic environment. Low DO $\left(1.39 \mathrm{mg} \mathrm{l}^{-1}\right)$ values in station $\mathrm{M}_{6}-\mathrm{M}_{7}$ may be due to the stagnant and non-flushing conditions of the water with increasing waste load in the mangrove environment. This in turn enhances the concentrations of ammonia $(14.2 \mu \mathrm{M})$ and nitrite $(6.49 \mu \mathrm{M})$ at these $\left(\mathrm{M}_{6}-\mathrm{M}_{7}\right)$ stations. High $\mathrm{NO}_{3}(21.4 \mu \mathrm{M})$ and $\mathrm{SiO}_{4}(142.0 \mu \mathrm{M})$ concentration observed in the estuarine station $\left(\mathrm{G}_{4}\right)$ indicates the impact of terrestrial runoff. The mean values and ranges of physico-chemical and biological parameters of the study area are given in table 1 .

The waters in KKD bay and GG estuarine environment are well oxygenated with the DO value ranging from 5.98 to 8.65 and 5.49 and $6.38 \mathrm{mg} \mathrm{l}^{-1}$ respectively. However, in the mangrove environment oxygen concentrations varied between 1.39 and $5.45 \mathrm{mg} \mathrm{l}^{-1}$. Low DO values 
(1.39-2.26 $\left.\mathrm{mg} \mathrm{l}^{-1}\right)$ were observed especially in Coringa river mangrove areas. However, the stations in Gaderu $\left(\mathrm{M}_{1}-\mathrm{M}_{2}\right)$ river mangrove systems experience high oxygen conditions (mean $5.45 \mathrm{mg} \mathrm{l}^{-1}$ ) since the river opens on one side into KKD bay and the other side into the Bay of Bengal at Bhairavpalem. High values of BOD (2.88-5.85 $\mathrm{mg} \mathrm{l}^{-1}$ ) in the KKD bay indicate the influence of domestic and agricultural wastes carried through the Godavari canal passing through the Kakinada township $\left(\mathrm{K}_{1}\right.$ : Jagannathpuram canal) adjoining the Kakinada bay. High BOD with low DO values in Coringa river $\left(\mathrm{M}_{3}-\mathrm{M}_{7}\right)$ mangrove systems may be due to contamination, either by the inflow of wastes from terrestrial runoff or of anthropogenic in origin, and is a cause for concern.

In general, high concentrations of nutrients were noticed in the mangrove environment compared to KKD bay and GG estuarine system (table 1). The average concentrations of $\mathrm{NO}_{2}, \mathrm{NH}_{4}, \mathrm{PO}_{4}$, and $\mathrm{SiO}_{4}$ were in the increasing order from KKD bay, GG estuary and mangrove environment. More or less of the same concentrations of $\mathrm{NO}_{3}$ have been noticed both in the GG estuary and in the mangrove environment. From the values of total nitrogen and inorganic nitrogen $\left(\mathrm{NO}_{2}, \mathrm{NO}_{3}\right.$ and $\left.\mathrm{NH}_{4}\right)$ in the study area, the percentage of organic nitrogen was estimated. The percentage composition of inorganic nitrogen in the GG estuarine was $73.93 \%$ of the total nitrogen whereas it was $45.06 \%$ in the mangrove environment which, clearly indicates that the mangrove ecosystems are better enriched with organic nitrogen (54.94\%) compounds compared to the estuarine environment $(26.07 \%)$. The percentage of inorganic phosphorous (33\%) of the total phosphorous was more or less same in all the three regions.

Estuarine mangrove waters in general have relatively low stocks of dissolved inorganic phosphorus and nitrogen (Alongi et al 1992). In some cases, the degree of human impact seems to control nutrient profiles (Nedwell 1975; Nixon et al 1984), while in others the degree of upland influence and the hydrology of the system appear to be of greater importance (Boto and Wellington 1988; Ovalle et al 1990). In the present study, the ecosystem was found to be nutrient rich, and the ratios of $\mathrm{N}: \mathrm{P}$ $(4: 1)$ as well as TN:TP $(3: 1)$ were low. Linear regression analyses were carried out to find out the relationships between salinity, DO and nutrients; and among the nutrients themselves (table 2). Significant positive correlations with high $R^{2}$ values especially for salinity vs. $\mathrm{SiO}_{4}\left(R^{2}=0.66\right)$ and DO $\left(R^{2}=0.49\right)$ indicate the influence of freshwater discharge in these ecosystems. Less significant correlations were noticed in case of salinity $v s$. $\mathrm{PO}_{4}\left(R^{2}=0.18\right)$ and $\mathrm{NO}_{3}\left(R^{2}=0.32\right)$ and among
Table 2. Regression analyses $\left(R^{2}\right)$ values among different parameters.

\begin{tabular}{lc}
\hline \multicolumn{1}{c}{ Parameters } & $\begin{array}{l}R^{2} \text { values } \\
(n=32)\end{array}$ \\
\hline Salinity vs. nitrite & 0.28 \\
Salinity vs. DO & 0.49 \\
Salinity vs. ammonium & 0.22 \\
Salinity vs. nitrate & 0.32 \\
Salinity vs. phosphate & 0.18 \\
Salinity vs. silicate & 0.66 \\
Nitrate vs. phosphate & 0.0004 \\
Nitrate vs. silicate & 0.19 \\
\hline
\end{tabular}

the nutrients themselves $\left(\mathrm{NO}_{3} / \mathrm{PO}_{4}: R^{2}=0.0004\right.$; $\left.\mathrm{NO}_{3} / \mathrm{SiO}_{4}: R^{2}=0.19\right)$. This lack of significant correlations indicates the influx of anthropogenic inputs and waste discharges containing nitrogen and phosphorous compounds from river runoff into these environments. Further, from this analysis, the $\mathrm{Si}: \mathrm{N}: \mathrm{P}$ ratios for the KKD bay $(18: 4: 1)$, GG estuarine region $(32: 6: 1)$ and mangrove environment $(34: 4: 1)$ were obtained and the average $\mathrm{Si}: \mathrm{N}: \mathrm{P}$ ratio in the entire study area was found to be $29: 4: 1$ which is comparatively lower than the normal Redfield ratios, and could be attributed to enrichment of these nutrients $\left(\mathrm{NO}_{3}\right.$ and $\mathrm{PO}_{4}$ compared to $\mathrm{SiO}_{4}$ ) through external inputs (Redfield et al 1963). The low $\mathrm{N}: \mathrm{P}$ ratio in these aquatic environments may be due to the slow regeneration of $\mathrm{NO}_{3}$ compared to $\mathrm{PO}_{4}$. The deficiency in the ratio of nitrogen to phosphate in many inshore areas (Steffansson and Richards 1963; Pratt 1965; Naqvi et al 1978; De Souza et al 1981; Sarma et al 1988; Justice et al 1995) may suggest that nitrogen is the limiting nutrient for photosynthesis.

Chlorophyll is considered as the most reliable index of phytoplankton biomass. Also, Chl $a: \mathrm{Pp}$ ratio provides the first hand information on the physiological status of phytoplankton. Hence, these pigments were studied simultaneously along with the phytoplankton composition and density. The high concentration of Chl $a$ observed in all the three regions may be due to the monsoonal runoff wherein high concentrations of nutrients are brought into these environments stimulating a rich phytoplankton growth (Subrahmanyan 1959, 1960). Average values of $\mathrm{Chl} a$ and $\mathrm{Pp}$ (12.49 and $7.92 \mu \mathrm{g} \mathrm{l}^{-1}$ ) are higher in KKD bay compared to GG estuarine regions (5.23 and $2.2 \mu \mathrm{g} \mathrm{l}^{-1}$ ) and mangrove environment (5.42 and $\left.3.16 \mu \mathrm{g} \mathrm{l}^{-1}\right)$. Low $\mathrm{Pp}$ values in GG estuary and mangrove regions compared to KKD bay, show less degradation of $\mathrm{Chl} a$ in these two regions. Higher fractions (mean) of $\mathrm{Pp}\left(3.16 \mu \mathrm{g} \mathrm{l}^{-1}\right)$ compared to Chl $a\left(5.42 \mu \mathrm{g} \mathrm{l}{ }^{-1}\right)$ in the Coringa river region indicate the presence of more detrital matter in these nonturbulent conditions which could be attributed to decomposition 
of organic matter, from the sediment and community structure, harbouring in the surrounding water.

The mean values of $\mathrm{Chl} b / \mathrm{Chl} a$ and $\mathrm{Chl} c / \mathrm{Chl} a$ ratios were 0.30 and 0.45 , and agrees fairly well with the earlier reported results from other marine environments (Neveux and Billy 1979; Lorenzen 1981), suggesting the possibility of potential growth of phytoplankton biomass in lower light intensity and low turbulent areas. The mean concentrations of $\mathrm{Chl} b$ were $1.1,0.61$ and $1.48 \mu \mathrm{g} \mathrm{l}^{-1}$ in KKD bay, GG estuary region and mangrove area, respectively. The presence of $\mathrm{Chl} b$ in the estuarine mangrove systems suggests that green algae also contributed significantly to primary production. Higher Pp concentrations $\left(7.92,2.2,3.16 \mu \mathrm{g} \mathrm{l}^{-1}\right)$ compared to $\mathrm{Chl} b\left(1.1,0.61,1.48 \mu \mathrm{g} \mathrm{l}^{-1}\right)$ and high ratios of $\mathrm{Chl} a / \mathrm{Pp}\left(2.0,2.21,2.45 \mu \mathrm{g} \mathrm{l}^{-1}\right)$ in the three regions indicate the growth of phytoplankton in the low light intensity and low turbulent waters of mangrove ecosystems (Saijo et al 1969; Takahashi and Nakamoti 1972).

\section{Summary and conclusion}

The hydrological parameters exhibited distinct variation in the three categorized study zones. High concentrations of nutrients in the mangrove environment compared to KKD bay and GG estuarine region reveal the importance of this zone as a source of nutrients to the adjacent ambience. Average salinity values (3.28 and $3.86 \mathrm{psu}$ ) of the mangrove and estuarine systems respectively, were noticed to be comparatively lower to the high values $(21.1 \mathrm{psu})$ in KKD bay, which is adjoining the coastal environment. Low salinity conditions $(0.27-9.48 \mathrm{psu})$ in the Coringa river region clearly indicate the influence of freshwater discharge from Coringa and Matlapalem channels into this region. The mean $\mathrm{Chl} b / \mathrm{Chl} a$ and $\mathrm{Chl} c / \mathrm{Chl} a$ ratios are $<1$ suggesting the possibility of healthy phytoplankton populations in lower light intensity and low turbulent areas also.

\section{Acknowledgements}

The authors are thankful to the Director, NIO and Dr. K S R Murthy, Scientist-in-Charge, NIO, Regional Centre, Visakhapatnam for their continuous support and inspiration throughout this work. We are thankful to the institutional funding for providing financial assistance for the work. The award of SRF by the HRDG-CSIR to one of the authors (SCT) is highly acknowledged. This is NIO contribution no. 3967.

\section{References}

Alongi D M, Boto K G and Robertson A I 1992 Nitrogen and phosphorus cycles, In: Tropical mangrove ecosystems; (eds) Robertson A I and Alongi D M, American Geophysical Union, Washington, D.C., Pp. 251-292.

Alongi D M and Christoffersen P 1992 Benthic infauna and organism-sediment relations in a shallow, tropical area influence of outweled mangrove detritus and physical disturbances; Mar. Ecol. Prog. Ser. 81 229-245.

Boto K G and Wellington J T 1988 Seasonal variations in concentration and fluxes of dissolved organic and inorganic materials in a tropical, tidally-dominated, mangrove waterway; Mar. Ecol. Prog. Ser. 50 151-160.

Bouillon S, Chandra Mohan P, Sreenivas N and Dehairs F 2000 Sources of suspended organic matter and selective feeding by zooplankton in an estuarine mangrove ecosystem as traced by stable isotopes; Mar. Ecol. Prog. Ser. 208 79-92.

Bouillon S, Frankignoulle M, Dehairs F, Verlimirov B, Eiler A, Etcheber H, Abril G and Borges A V 2003 Inorganic and organic carbon biogeochemistry in the Gautami Godavari estuary (Andhra Pradesh, India) during pre-monsoon: the local impact of extensive mangrove forests; Global biogeochemical cycles 17(4) 114, doi: 10.1029/2002GB002026.

Clough B F 1992 Primary productivity and growth of mangrove forests, In: Tropical mangrove ecosystems; (eds) Robertson A I and Alongi D M, American Geophysical Union, Washington, D.C., Pp. 225-249.

De Souza S N, Naqvi S W A and Reddy C V G 1981 Distribution of nutrients in the western Bay of Bengal; Indian J. Mar. Sci. $10327-331$.

Dehairs F, Rao R G, Chandra Mohan P, Raman A V, Marguillier S and Hellings L 2000 Tracing mangrove carbon in suspended matter and aquatic fauna of the GautamiGodavari Delta, Bay of Bengal (India); Hydrobiologia 431 225-241.

Grasshoff K 1976 Determination of dissolved oxygen and nutrients, In: Methods of Sea water analysis; (eds) Grashoff K, Ehrhardt M and Kremling K, Verlag Chemie, Weinheim, Denmark, Pp. 1-260.

Justice D, Rabalais N N and Turner R E 1995 Stoichiometric nutrient balance and origin of coastal eutrophication Mar. Poll. Bull. 30 41-46.

Lorenzen C J 1981 Chlorophyll $b$ in the eastern North Pacific Ocean; Deep Sea Res. 28 1049-1056.

Naqvi S W A, DeSouza S N and Reddy C V G 1978 Relationship between nutrients and dissolved oxygen with special reference to water masses in western Bay of Bengal; Indian J. Mar. Sci. 7 15-17.

Nedwell D B 1975 Inorganic nitrogen metabolism in a eutrophicated tropical mangrove estuary; Water Res. 9 $221-231$.

Neveux J and Billy G 1979 Spectrofluorometric determination of chlorophylls and phaeophytins. Their distribution in the western part of the Indian Ocean (July to August, 1979); Deep Sea Res. 33 1-14.

Nixon S W, Furnas B N, Lee V, Marshall N, Ong J E, Wong C H, Gong W K and Sasekumar A 1984 The role of mangroves in the carbon and nutrient dynamics of Malaysia estuaries, In: Proceedings of the Asian Symposium on Mangrove Environment: research and management; (eds) Soepadmo E, Rao A N and Macintosh D J, University of Malaya, Kuala Lumpur, Pp. 535-554.

Odum W E and Heald E J 1975 The detritus based food web of an estuarine mangrove community, In: Estuarine Research; (ed.) Cronin L E, Academic Press, New York, Pp. 265-286. 
Odum W E and Heald E J 1972 Trophic analysis of an estuarine mangrove community; Bull. Mar. Sci. 22 $671-738$.

Ovalle A R C, Rezende C E, Lacerda L D and Silva C A R 1990 Factors affecting the hydrochemistry of a mangrove tidal creek, Sepetiba Bay, Brazil; Estuar. Coast. Self Sci. 31 639-650.

Parsons T R, Maita Y and Lalli C M 1984 A Manual of Chemical and Biological Methods for Seawater Analysis, Pergamon Press, United Kingdom.

Pratt D M 1965 The winter spring diatom flowering in Narrangansett Bay; Limnol. Oceanogr. 10173.

Ranga Rao V, Reddy B S R, Raman A V and Ramana Murthy M V 2003 Oceanographic features of the Baymangrove waterways of Coringa, East coast of India; Proc. of AP Akademi of Sciences 7(2) 135-142.

Redfield A C, Ketchum B H and Richards F A 1963 The influence of organisms on the composition of seawater, In: The sea (ed.) Hill M N, (New York: Willey) 2 26-77.

Robertson A I, Alongi D M and Boto K G 1992 Food chains and carbon fluxes In: Tropical mangrove ecosystems (eds) Robertson A I and Alongi D M, American Geophysical Union, Washington, D.C., Pp. 293-326.

Saijo Y, Iiznka S and Asaoka O 1969 Chlorophyll maxima in Kuroshio and adjacent area; Mar. Biol. 4 190-196.

Sarma V V, Rao T V N, Rama Raju V S, Vijayakumar R and Suguna C 1988 Interrelationships and distribution of hydrochemical parameters in coastal waters off Visakhapatnam, east coast of India; Mahasagar-Bull. Nat. Inst. Oceanogr. 21 197-207.

Sreenivas N 1998 Zooplankton production and distribution in mangrove habitat of Godavari Estuary - Kakinada; Ph.D. thesis, Andhra University, India.

Steffansson V and Richards F A 1963 Processes contributing to the nutrient distributions off the Columbia River and strait of Juan De Fuza; Limnol. Oceanogr. 8 394.

Subrahmanyan R 1959 Studies on the phytoplankton of the west coast of India; Parts I and II, Proc. Indian Acad. Sci. 50 113-252.

Subrahmanyan R 1960 Observations on the effect of the monsoons in the production of Phytoplankton; J. Indian Bot. Sci. 39 78-89.

Takahashi M K S and Nakamoti N 1972 Chlorophyll distribution and photosynthetic activity in the North and Equatorial Pacific Ocean along $155^{\circ} \mathrm{W} ;$ J. Oceanogr. Soc. Japan 28 27-34.

Twilley R R 1988 Coupling of mangroves to the productivity of estuarine and coastal waters, In: Coastal-Offshore Ecosystem Interactions; (ed.) Jansson B O, Germany: Springer-Verlag, Pp. 155-180.

Wattayakorn G, Wolanski E and Kjerfve B 1990 Mixing, trapping and outwelling in the Klong Ngao mangrove swamp, Thailand; Estuar. Coast. Shelf Sci. 31 667-688. 